\title{
Creditor Nations' Equity Indexes and the U.S. Debt Downgrade
}

\author{
Srinivas Nippani ${ }^{1} \&$ Kenneth Washer ${ }^{2}$ \\ ${ }^{1}$ College of Business and Entrepreneurship, Texas A\&M University-Commerce, Commerce, Texas, USA \\ ${ }^{2}$ College of Business Administration, Creighton University, Omaha, Nebraska, USA \\ Correspondence: Kenneth Washer, Creighton University, College of Business Administration, Department of \\ Economics and Finance, 2500 California Plaza, Omaha, NE 68178, USA. E-mail: kenwasher@creighton.edu
}

Received: April 2, 2012

Accepted: April 23, $2012 \quad$ Published: June 1, 2012

doi:10.5539/ijef.v4n6p3

URL: http://dx.doi.org/10.5539/ijef.v4n6p3

\begin{abstract}
On Friday, August 5, 2011 Standard and Poor's rating agency downgraded long-term U.S. Treasury debt from AAA to $\mathrm{AA}+$ for the first time in history. In this study, the impact of this downgrade on world stock markets is examined. We analyze the immediate effect of this downgrade on leading stock indices of 31 nations owning U.S. Treasury debt. We find that the downgrade had a marked effect on the first trading day following the announcement. It truly was a macroeconomic event. We further examine whether return differentials were partially explained by the level of U.S. debt that each country possessed (both on an absolute and relative basis). We find no evidence of this relationship, which suggests equity markets in countries owning considerable Treasury securities suffered no more or less than equity markets in countries with less U.S. Treasury debt.
\end{abstract}

Keywords: economic integration, information and market efficiency, event studies

\section{Introduction}

When the U.S. equity markets closed on Friday, August 5, 2011 Standard and Poor's (S\&P) rating agency downgraded the credit rating of long term U.S. Treasury securities from AAA to AA+. The rating agency (Note 1) included the following phrases in its downgrade announcement "On political risks and raising debt burden" and "Outlook Negative". This downgrade and its impact were discussed widely in the popular press in the days following the announcement. For example, in an article in The Guardian (U.K.), Elliott, Treanor and Rushe (2011) mention (Note 2):

"The United States lost its AAA credit rating late on Friday night, ending another wild day on the world stock markets and prompting fears that next week could be equally as calamitous."

and

"This is the first time that S\&P has issued a "negative" outlook to the U.S. government since it began rating the credit-worthiness of railroad bonds in 1860. The dramatic reversal of fortune for the world's largest economy means that U.S. Treasuries, once seen as the safest investment in the world, are now rated lower than bonds issued by countries such as U.K., Germany or France. The move is likely to raise the borrowing costs for the American government, companies and consumers."

In another article published on August 8, 2011, Meinero states:

"European stocks closed sharply lower Monday, as action to bolster faltering Eurozone nations couldn't overcome concerns about Standard and Poor's downgrade of U.S. debt. Asian markets also finished lower." (Note 3)

Numerous other newspaper headlines and finance blogs referred to the downgrade and its impact on world stock markets. The issue was prominently debated all weekend and speculation on the depth of the stock market decline when markets opened on Monday was wide.

There are two main purposes of this paper. First, we examine the stock market returns of the leading market indices of 31 nations holding U.S. Treasury debt just prior to the downgrade. Second, we test whether stock returns in countries with large holdings of U.S. Treasury debt were more severely affected than countries with smaller holdings. While we find that the markets reacted negatively to the rating change, there appears to be no relationship between the level of Treasury debt held and the return on a country's stock market. Our results are robust in that we consider Treasury holdings both as on an absolute basis and a relative basis (as a percentage of GDP). Thus, we 
conclude that while there was a negative reaction to the downgrade in all stock markets, it was not impacted by the size of a country's Treasury holdings.

A few studies in the past ten years have looked at the impact of changes in sovereign credit ratings on stock markets. Brooks, Faff, Hillier and Hillier (2004) were among the first to look at aggregate stock market returns surrounding sovereign credit rating changes. Their sample includes rating changes over the period 1973-2000. With regard to rating downgrades, they find that the event day impact is significantly negative. While the Brooks et. al. (2004) study concentrated on market returns in countries that were re-rated, Ferreira and Gama (2007) study the impact of cross-country stock market reactions to S\&P's announcements of sovereign credit rating or credit outlook changes. They show that debt rating and credit outlook changes for one sovereign have an asymmetric and economically significant effect on stock markets of other countries over the period 1989-2003. An interesting study by Hooper, Hume and Kim (2008) finds that rating downgrades significantly decreased dollar denominated stock market returns and increased volatility. They also analyze upgrades and find that the results are the opposite in a data set of 42 countries covering the major regions of the world over the period 1995-2003. Pukthuanthong-Le, Elayan and Rose (2007) examine the changes in sovereign credit ratings on bonds and stocks over the 1990-2000 period. They show that stock market responses for downgrade are more pronounced under certain conditions.

Our research investigates the impact of just one such downgrade in sovereign credit ratings, the S\&P rating change of long-term U.S. Treasury debt. We focus on the impact this downgrade had on stock markets in 31 countries that hold several billion dollars of their taxpayers' money in U.S. Treasury debt. Our research differs from prior studies in several ways. First, we examine the impact on equity markets around the world of a single rating downgrade, specifically the rating downgrade of the wealthiest country and the largest economy in the world. Since this is the first time U.S. Treasuries have been downgraded and considering that other sovereign credit ratings changes impacted stock markets, one logically expects the U.S. downgrade to have a significant impact on equity markets.

Finance textbooks and professionals across the globe routinely use the U.S. Treasury rate as the risk-free rate. A rating downgrade for the U.S. was previously unheard of and therefore is likely to reverberate throughout the world since U.S. Treasury rates technically are not risk-free. As mentioned by Elliott, Treanor and Rushe (2011) in the popular press, other countries such as the U.K., France and Germany all have a superior credit rating to the U.S. The force of this landmark financial event is likely to affect markets throughout the world. This is a classic example of a systematic event, one which virtually no asset is immune. Alternatively, many people have little faith in the rating agencies following their less than stellar performance in the time leading up to the financial crisis, which began in 2008. One may also argue that the information is not new information. The other major rating agencies did not downgrade U.S. debt.

A second way our study differs is that virtually every major economy in the world has invested heavily in U.S. Treasury securities, and we factor this level of investment into our analysis. Led by Mainland China, whose investment in Treasury securities exceeded $\$ 1$ trillion as of July 2011, several of the leading nations in the world have invested a great deal in U.S. debt. The complete list of countries is given in Table 1. We surmise that countries having large investments in U.S. Treasuries may see a more pronounced impact from the downgrade. A downgrade generally leads to a reduction in the market price of the asset. Thus, one would expect Treasuries to be worth less following the downgrade. A decrease in the value of Treasuries means larger future taxes for citizens and corporations in the long run should the investor governments decide to sell some or all of these securities in the market. Considering that several countries have invested in excess $\$ 100$ billion in Treasuries, we also investigate whether the holding size is related to the magnitude of the stock market return.

The remainder of the paper is organized as follows: In section two, we present the data used in the study and develop our hypothesis. We present the empirical evidence in the third section and conclude in the last section.

\section{Data}

We gathered data from several sources: First, we obtained the data for the list of countries owning U.S. Treasuries from Treasury's website (Note 4). A table entitled "Major Foreign holders of Treasury Securities" lists 31 nations and also includes other major investors like "Oil Exporters" and "Caribbean Banking Centers." Both are excluded from the study because they have no associated stock index. We use data as of July 2011, which closely matches the event period. We also select a leading stock market index for each country. Table 1 lists the countries, the leading equity index, the index's Bloomberg ticker symbol and the dollar value of Treasury holdings.

The daily closing values for the stock indices and gross domestic product (GDP) figures are obtained from Bloomberg. GDP data is for the second quarter of 2011. These values are in U.S. dollars, which is consistent with the market value of Treasury holdings. 
Table 1. U.S. Treasury Security Holdings by Country

\begin{tabular}{|c|c|c|c|}
\hline Country & Equity Index & Bloomberg Ticker & Holdings (billions) \\
\hline China, Mainland & CSI 300 & SHSZ300 & $\$ 1,173.5$ \\
\hline Japan & NIKKEI 225 & NKY & 914.8 \\
\hline United Kingdom & FTSE 100 & UKX & 353.4 \\
\hline Brazil & Brazil Bovespa & IBOV & 210.0 \\
\hline Taiwan & Taiwan TAIEX & TWSE & 154.3 \\
\hline Switzerland & Swiss Market & SMI & 108.4 \\
\hline Hong Kong & Hang Seng & HSI & 111.9 \\
\hline Russia & MICEX & INDEXCF & 100.7 \\
\hline Canada & S\&P/TSX Composite & SPTSX & 83.5 \\
\hline Luxembourg & LuxX & LUXXX & 61.4 \\
\hline Germany & DAX & DAX & 61.2 \\
\hline Singapore & FTSE Straits Times & FSSTI & 63.0 \\
\hline Thailand & Thai SET 50 & SET & 65.2 \\
\hline Turkey & ISE National 100 & XU100 & 41.9 \\
\hline India & BSE SENSEX 30 & SENSEX & 37.9 \\
\hline Ireland & Irish Overall & ISEQ & 34.3 \\
\hline South Korea & KRX 100 & KRX100 & 29.4 \\
\hline Belgium & BEL 20 & BEL20 & 31.3 \\
\hline France & CAC 40 & CAC & 22.5 \\
\hline Poland & WSE WIG & WIG & 29.3 \\
\hline Mexico & Mexico IPC & MEXBOL & 29.1 \\
\hline Philippines & PSEi & PCOMP & 25.1 \\
\hline Italy & FTSE MIB & FTSEMIB & 24.3 \\
\hline Netherlands & AEX & AEX & 23.2 \\
\hline Norway & OBX & OBX & 17.6 \\
\hline Sweden & Stockholm 30 & OMX & 21.3 \\
\hline Colombia & Columbia COLCAP & COLCAP & 20.0 \\
\hline Chile & Chile Stock Market Select & IPSA & 18.0 \\
\hline Israel & Tel Aviv 25 & TA-25 & 17.2 \\
\hline Malaysia & FTSE Bursa Malaysia & FBMKLCI & 13.3 \\
\hline Australia & S\&P/ASX 200 & AS51 & 13.1 \\
\hline
\end{tabular}

*Source: Department of the Treasury/Federal Reserve Board (Name of Country and Holdings) and Bloomberg

Website: http://www.treasury.gov/resource-center/data-chart-center/tic/Documents/mfh.txt

\section{Empirical Evidence}

\subsection{Regression Analysis of Daily Returns}

We first calculate the daily returns for each index shown in Table 1 . The daily percentage returns are calculated for the period 5-31-2010 through 8-12-2011 using Equation 1.

$$
R_{t}=\left[\left(C V I_{t}-C V I_{t-1}\right) / C V I_{t-1}\right] * 100
$$

In the above equation, $r_{t}$ is the return on the index for day $t$, and $\mathrm{CVI}_{t}$ and $\mathrm{CVI}_{\mathrm{t}-1}$ are the daily closing values of the index at the end of day $t$ and the previous day, $t-1$. Thus, we end up with daily percentage returns for each of the 31 indices.

S\&P's downgrade was announced after the U.S. markets closed on 8-5-2011. Regression Model A is employed to measure the impact of the announcement.

$$
\text { Regression Model A: } R_{t}=\beta_{0}+\beta_{1} d_{a y_{1}}+\beta_{2} \text { day }_{2 \notin 3}+\beta_{3} \text { day }_{4 \& 5}+\varepsilon
$$

The daily percentage return is the dependent variable in the regression, and it covers a period of approximately 300 days. For some indices, the sample period is slightly above or below this level due to mismatch of holidays among countries. The return from the close on 8-5-2011 to 8-8-2011 is considered the dayl return for all indices. This day reflects the first trading day post-announcement. We separate the post-announcement week into three binary variables: $d a y_{1}$ takes a value of one for 8-8-2011, zero otherwise. We want to separate the event day based on the result of Brooks, et. al. (2004), who find a significant negative impact for downgrades on event day. Also, this day is 
likely to reflect market reaction more than a group of days since it covers the weekend when the downgrade was discussed widely in the popular press across the world. day $2 \& 3$ represents a dummy variable assigned a value of one for the two days 8-9-2011 and 8-10-2011, zero otherwise. day $4 \& 5$ is the third dummy variable and is set to one for the two trading days 8-11-2011 and 8-12-2011, and zero otherwise. The results of the 31 regressions are displayed in Table 2 .

Table 2. Regression Model A

\begin{tabular}{|c|c|c|c|c|c|c|c|c|}
\hline Country & Bloomberg Ticker & $\begin{array}{l}\text { Constant } \\
\text { (t-stat) }\end{array}$ & $\begin{array}{l}\text { Day }_{1} \\
\text { (t-stat) }\end{array}$ & $\begin{array}{l}\mathrm{Day}_{2 \& 3} \\
\text { (t-stat) }\end{array}$ & $\begin{array}{l}\text { Day }_{4 \& 5} \\
\text { (t-stat) }\end{array}$ & $\mathrm{N}$ & $\mathrm{R}^{2}$ & F-value \\
\hline China & HSI & $\begin{array}{l}0.01 \\
(0.16)\end{array}$ & $\begin{array}{l}-3.80 \\
(-49.39 *)\end{array}$ & $\begin{array}{l}0.43 \\
(2.78 *)\end{array}$ & $\begin{array}{l}0.85 \\
(5.92 *)\end{array}$ & 294 & 0.04 & 0.015 \\
\hline Japan & NKY & $\begin{array}{l}-0.01 \\
(-0.08)\end{array}$ & $\begin{array}{l}-2.17 \\
\left(-27.55^{*}\right)\end{array}$ & $\begin{array}{l}-0.31 \\
(-0.77)\end{array}$ & $\begin{array}{l}-0.41 \\
\left(-4.18^{*}\right)\end{array}$ & 298 & 0.01 & 0.482 \\
\hline UK & UKX & $\begin{array}{l}0.01 \\
(0.13)\end{array}$ & $\begin{array}{l}-3.40 \\
(-52.94 *)\end{array}$ & $\begin{array}{l}-0.59 \\
(-0.81)\end{array}$ & $\begin{array}{l}3.07 \\
(46.65 *)\end{array}$ & 306 & 0.09 & 0.000 \\
\hline Brazil & IBOV & $\begin{array}{l}-0.05 \\
(-0.75)\end{array}$ & $\begin{array}{l}-8.03 \\
\left(-115.55^{*}\right)\end{array}$ & $\begin{array}{l}2.84 \\
\left(4.15^{*}\right)\end{array}$ & $\begin{array}{l}2.07 \\
(3.94 *)\end{array}$ & 301 & 0.18 & 0.000 \\
\hline Taiwan & TWSE & $\begin{array}{l}0.03 \\
(0.42)\end{array}$ & $\begin{array}{l}-3.85 \\
(-62.23 *)\end{array}$ & $\begin{array}{l}1.20 \\
\left(2.07^{*}\right)\end{array}$ & $\begin{array}{l}-0.67 \\
(-4.67 *)\end{array}$ & 302 & 0.06 & 0.000 \\
\hline Switzerland & SMI & $\begin{array}{l}-0.06 \\
(-0.96)\end{array}$ & $\begin{array}{l}-3.88 \\
\left(-60.41^{*}\right)\end{array}$ & $\begin{array}{l}-1.70 \\
\left(-2.43^{*}\right)\end{array}$ & $\begin{array}{l}4.76 \\
(40.04 *)\end{array}$ & 308 & 0.20 & 0.000 \\
\hline Hong Kong & HIS & $\begin{array}{l}0.03 \\
(0.38)\end{array}$ & $\begin{array}{l}-2.20 \\
(-33.28 *)\end{array}$ & $\begin{array}{l}-1.68 \\
(-1.46)\end{array}$ & $\begin{array}{l}-0.44 \\
(-2.64 *)\end{array}$ & 301 & 0.03 & 0.030 \\
\hline Russia & INDEXCF & $\begin{array}{l}0.07 \\
(0.94)\end{array}$ & $\begin{array}{l}-5.56 \\
(-78.77 *)\end{array}$ & $\begin{array}{l}-2.35 \\
\left(-3.69^{*}\right)\end{array}$ & $\begin{array}{l}1.30 \\
\left(5.19^{*}\right)\end{array}$ & 301 & 0.09 & 0.000 \\
\hline Canada & SPTSX & $\begin{array}{l}0.01 \\
(0.28)\end{array}$ & $\begin{array}{l}-4.05 \\
\left(-78.15^{*}\right)\end{array}$ & $\begin{array}{l}2.23 \\
(4.99 *)\end{array}$ & $\begin{array}{l}1.39 \\
(3.38 *)\end{array}$ & 303 & 0.13 & 0.000 \\
\hline Luxembourg & LUXXX & $\begin{array}{l}-0.04 \\
(-0.69)\end{array}$ & $\begin{array}{l}-4.33 \\
\left(-74.15^{*}\right)\end{array}$ & $\begin{array}{l}-1.61 \\
\left(-4.20^{*}\right)\end{array}$ & $\begin{array}{l}1.76 \\
\left(7.78^{*}\right)\end{array}$ & 308 & 0.08 & 0.000 \\
\hline Germany & DAX & $\begin{array}{l}0.02 \\
(0.28)\end{array}$ & $\begin{array}{l}-5.04 \\
\left(-70.81^{*}\right)\end{array}$ & $\begin{array}{l}-2.64 \\
\left(-3.55^{*}\right)\end{array}$ & $\begin{array}{l}3.35 \\
(45.65 *)\end{array}$ & 311 & 0.15 & 0.000 \\
\hline Singapore & FSSTI & $\begin{array}{l}0.03 \\
(0.64)\end{array}$ & $\begin{array}{l}-3.73 \\
(-76.28 *)\end{array}$ & $\begin{array}{l}-1.56 \\
\left(-8.30^{*}\right)\end{array}$ & $\begin{array}{l}1.36 \\
\left(7.88^{*}\right)\end{array}$ & 306 & 0.11 & 0.000 \\
\hline Thailand & SET & $\begin{array}{l}0.13 \\
(2.30 *)\end{array}$ & $\begin{array}{l}-1.52 \\
\left(-25.95^{*}\right)\end{array}$ & $\begin{array}{l}-0.94 \\
(-1.30)\end{array}$ & $\begin{array}{l}1.09 \\
\left(3.55^{*}\right)\end{array}$ & 295 & 0.02 & 0.110 \\
\hline Turkey & XU100 & $\begin{array}{l}0.02 \\
(0.25)\end{array}$ & $\begin{array}{l}-7.10 \\
\left(-90.13^{*}\right)\end{array}$ & $\begin{array}{l}-1.88 \\
(-2.02 *)\end{array}$ & $\begin{array}{l}1.84 \\
(4.00 *)\end{array}$ & 306 & 0.11 & 0.000 \\
\hline India & SENSEX & $\begin{array}{l}0.01 \\
(0.19)\end{array}$ & $\begin{array}{l}-1.84 \\
\left(-27.45^{*}\right)\end{array}$ & $\begin{array}{l}0.41 \\
(1.16)\end{array}$ & $\begin{array}{l}-0.86 \\
(-5.90 *)\end{array}$ & 307 & 0.01 & 0.214 \\
\hline Ireland & ISEQ & $\begin{array}{l}-0.05 \\
(-0.65)\end{array}$ & $\begin{array}{l}-4.37 \\
(-61.44 *)\end{array}$ & $\begin{array}{l}0.37 \\
(0.48)\end{array}$ & $\begin{array}{l}2.32 \\
(11.97 *)\end{array}$ & 307 & 0.06 & 0.000 \\
\hline S.Korea & KRX100 & $\begin{array}{l}0.06 \\
(0.99)\end{array}$ & $\begin{array}{l}-3.68 \\
(-58.72 *)\end{array}$ & $\begin{array}{l}-2.01 \\
\left(-4.21^{*}\right)\end{array}$ & $\begin{array}{l}-0.71 \\
(-2.50 *)\end{array}$ & 303 & 0.06 & 0.000 \\
\hline Belgium & BEL20 & $\begin{array}{l}-0.03 \\
(-0.51)\end{array}$ & $\begin{array}{l}-3.73 \\
\left(-57.26^{*}\right)\end{array}$ & $\begin{array}{l}-0.03 \\
(-0.03)\end{array}$ & $\begin{array}{l}4.06 \\
\left(9.44^{*}\right)\end{array}$ & 313 & 0.12 & 0.000 \\
\hline France & CAC & $\begin{array}{l}-0.01 \\
(-0.19)\end{array}$ & $\begin{array}{l}-4.66 \\
\left(-59.47^{*}\right)\end{array}$ & $\begin{array}{l}-1.90 \\
(-1.82)\end{array}$ & $\begin{array}{l}3.47 \\
\left(19.47^{*}\right)\end{array}$ & 313 & 0.10 & 0.000 \\
\hline Poland & WIG & $\begin{array}{l}0.01 \\
(0.13)\end{array}$ & $\begin{array}{l}-3.52 \\
(-65.01 *)\end{array}$ & $\begin{array}{l}-3.99 \\
\left(-38.91^{*}\right)\end{array}$ & $\begin{array}{l}3.34 \\
\left(13.06^{*}\right)\end{array}$ & 306 & 0.25 & 0.000 \\
\hline Mexico & MEXBOL & $\begin{array}{l}0.02 \\
(0.40)\end{array}$ & $\begin{array}{l}-5.90 \\
\left(-117.33^{*}\right)\end{array}$ & $\begin{array}{l}0.78 \\
(2.01 *)\end{array}$ & $\begin{array}{l}1.77 \\
\left(2.45^{*}\right)\end{array}$ & 307 & 0.16 & 0.000 \\
\hline Philippines & PCOMP & $\begin{array}{l}0.11 \\
(1.75)\end{array}$ & $\begin{array}{l}-2.50 \\
\left(-40.71^{*}\right)\end{array}$ & $\begin{array}{l}-0.52 \\
(-0.49)\end{array}$ & $\begin{array}{l}0.26 \\
\left(3.65^{*}\right)\end{array}$ & 301 & 0.02 & 0.076 \\
\hline Italy & FTSEMIB & $\begin{array}{l}-0.06 \\
(-0.60)\end{array}$ & $\begin{array}{l}-2.29 \\
\left(-25.09^{*}\right)\end{array}$ & $\begin{array}{l}-3.01 \\
\left(-2.85^{*}\right)\end{array}$ & $\begin{array}{l}4.10 \\
(44.02 *)\end{array}$ & 311 & 0.08 & 0.000 \\
\hline
\end{tabular}




\begin{tabular}{|c|c|c|c|c|c|c|c|c|}
\hline Netherlands & AEX & $\begin{array}{l}-0.02 \\
(-0.31)\end{array}$ & $\begin{array}{l}-4.36 \\
\left(-65.19^{*}\right)\end{array}$ & $\begin{array}{l}-1.03 \\
(-1.48)\end{array}$ & $\begin{array}{l}2.63 \\
\left(14.06^{*}\right)\end{array}$ & 313 & 0.10 & 0.000 \\
\hline Norway & OBX & $\begin{array}{l}0.03 \\
(0.37)\end{array}$ & $\begin{array}{l}-5.53 \\
\left(-65.46^{*}\right)\end{array}$ & $\begin{array}{l}-0.16 \\
(-0.42)\end{array}$ & $\begin{array}{l}3.15 \\
(19.40 *)\end{array}$ & 307 & 0.09 & 0.000 \\
\hline Sweden & OMX & $\begin{array}{l}-0.00 \\
(-0.07)\end{array}$ & $\begin{array}{l}-4.82 \\
\left(-69.03^{*}\right)\end{array}$ & $\begin{array}{l}0.19 \\
(0.22)\end{array}$ & $\begin{array}{l}2.90 \\
\left(12.19^{*}\right)\end{array}$ & 306 & 0.09 & 0.000 \\
\hline Colombia & COLCAP & $\begin{array}{l}0.04 \\
(0.55)\end{array}$ & $\begin{array}{l}-3.35 \\
(-48.52 *)\end{array}$ & $\begin{array}{l}1.48 \\
(3.93 *)\end{array}$ & $\begin{array}{l}0.87 \\
(8.74 *)\end{array}$ & 297 & 0.05 & 0.001 \\
\hline Chile & IPSA & $\begin{array}{l}0.02 \\
(0.30)\end{array}$ & $\begin{array}{l}-6.94 \\
\left(-109.51^{*}\right)\end{array}$ & $\begin{array}{l}4.13 \\
(8.22 *)\end{array}$ & $\begin{array}{l}1.75 \\
\left(6.53^{*}\right)\end{array}$ & 305 & 0.27 & 0.000 \\
\hline Israel & TA-25 & $\begin{array}{l}0.03 \\
(0.49)\end{array}$ & $\begin{array}{l}-7.01 \\
\left(-128.88^{*}\right)\end{array}$ & $\begin{array}{l}-0.68 \\
(-1.08)\end{array}$ & $\begin{array}{l}1.78 \\
(6.32 *)\end{array}$ & 298 & 0.17 & 0.000 \\
\hline Malaysia & FBMKLCI & $\begin{array}{l}0.06 \\
(1.85)\end{array}$ & $\begin{array}{l}-1.86 \\
\left(-58.16^{*}\right)\end{array}$ & $\begin{array}{l}-0.60 \\
(-1.87)\end{array}$ & $\begin{array}{l}0.05 \\
(0.42)\end{array}$ & 301 & 0.00 & 0.002 \\
\hline Australia & AS51 & $\begin{array}{l}0.06 \\
(1.85) \\
\end{array}$ & $\begin{array}{l}-1.86 \\
\left(-58.16^{*}\right)\end{array}$ & $\begin{array}{l}-0.60 \\
(-1.87) \\
\end{array}$ & $\begin{array}{l}0.05 \\
(0.42)\end{array}$ & 301 & 0.05 & 0.002 \\
\hline \multicolumn{2}{|c|}{ Average of Estimates } & $\mathrm{n} / \mathrm{a}$ & $-4.09 \%$ & $-0.51 \%$ & $1.68 \%$ & & & \\
\hline
\end{tabular}

*significant at $1 \%$ level.

Table 2 reports that the intercept is insignificant for all but one of the 31 regressions with the exception of Thailand's SET index. The intercept measures the average return when all binary variables are zero. Thus, over this period the average daily return was insignificantly different from zero in all cases but one. The $d_{a} y_{l}$ variable is significantly negative at the $1 \%$ level for all indices, which indicates that in all cases the return on this day was at least several standard deviations below the average of the preceding period. Thus, there is little doubt that the downgrade announcement caused equity investors to reduce their value estimates for stocks around the world.

The results for the second dummy variable $\left(d a y_{2 \& 3}\right)$ are conflicting. The coefficient estimate is significantly positive for China, Brazil, Taiwan, Mexico, Columbia and Chile. These markets all had strong stock market rebounds. In Switzerland, Russia, Canada, Luxembourg, Germany, Singapore, Turkey, South Korea, Poland and Italy, the coefficient estimate is significantly negative suggesting continuing strong downturns in stocks. The coefficients for the other countries were insignificantly different from the average daily return prior to the downgrade. The third dummy variable $\left(d a y_{4 \& 5}\right)$ shows a pattern similar to the $d a y_{2 \& 3}$ dummy variable, although many more coefficient estimates are significant ( 24 are strongly positive and 3 are strongly negative). This is noteworthy because it appears that the market partially or fully recovered from the event. The last row in the table indicates that on average the markets in these countries fell by $4.09 \%$ on the first trading day post-announcement. Over the entire week, the average market downturn for the indexes was a more modest $2.91 \%$ on average.

A second plausible interpretation of the regression output is that on Monday, markets around the world reacted negatively to the downgrade. This was an unexpected, Titanic-like event that overwhelmed markets throughout the world. On Tuesday and Wednesday, stock markets moved with much less coordination. Non-systematic events caused some markets to be up, while others were down. Thursday and Friday was much like Tuesday and Wednesday.

In the next subsection, we analyze the negative returns on $d a y_{1}$ for affected nations.

\subsection{Analysis of Day ${ }_{1}$ Negative Returns}

Ferreira and Gama (2007) study whether the news of sovereign debt ratings in one country impact stock markets in other countries. They configure a large set of countries that experienced sovereign debt upgrades and/or downgrades. In total they have 18 emerging markets and 11 developed ones. Our study differs as it examines the influence a single debt downgrade on the world's largest government has on stock markets. U.S. Treasury debt is unique in that a significant portion of it is held by other nations. In absolute terms, the U.S. debt held by other countries is extremely significant. This in itself lends credibility to the U.S. Treasury debt. This also appears as a vote of confidence for the U.S. by foreign governments. This debt has been rated AAA since ratings began and while the U.S. Treasury debt had been placed on "Creditwatch" earlier by rating agencies like Moody's (Note 5) it has never relinquished its AAA rating prior to 8-5-2011. There was a default by the U.S. Treasury, a technical one in 1979 (Zivney and Marcus, 1989). Evidence of default risk premiums on short-term and long-term U.S. Treasury securities was documented by Nippani, Liu and Schulman (2001) and Nippani and Smith (2010). However, none of these impacted the creditworthiness of the Treasury debt of the U.S. in the eyes of the rating agencies until recently. 
We examine the possible relation between market downturns on $d a y_{1}$ and the amount of U.S. Treasury debt owned by sovereigns. Since the $d a y_{l}$ return was significantly negative in all 31 countries, we use the return for $d a y_{l}$ as the dependent variable in the following two regressions:

$$
\begin{gathered}
\text { Regression Model B: day } y_{I x}=\beta_{0}+\beta_{I}\left(\text { Treasury }_{x}\right)+\varepsilon \\
\text { Regression Model C: day } y_{I x}=\beta_{0}+\beta_{I}\left(\text { Treasury }_{x} / G D P_{x}\right)+\varepsilon
\end{gathered}
$$

Regression Model B examines whether the negative return on $\operatorname{day}_{l}$ can be partially explained by the level of Treasury debt held by country $\mathrm{x}$ (Treasury $\mathrm{x}$ ). For example, Mainland China owned over $\$ 1,173.5$ billion of U.S. debt at the end of July 2011. This is much more than the $\$ 13.1$ billion owned by Australia. A negative relationship between the level of Treasury debt held and a country's stock market performance is hypothesized.

Regression Model C examines whether the $d a y_{1}$ return can be partially explained by U.S. Treasury holdings scaled by country x's GDP (Treasury ${ }_{\mathrm{x}} / \mathrm{GDP}_{\mathrm{x}}$ ). Again, a negative relationship is anticipated. Hypothetically, equity investors may be more concerned with the economies of countries that have the equivalent of $20 \%$ of GDP invested in U.S. Treasuries versus ones that have $2 \%$ of GDP invested in Treasuries. The results of these two regressions are shown in Table 3.

Table 3. Regression Results

\begin{tabular}{lcccccc}
\hline & $\begin{array}{c}\text { Independent } \\
\text { Variable }\end{array}$ & $\begin{array}{c}\text { Constant } \\
(\text { t-stat })\end{array}$ & $\begin{array}{c}\text { Coef. Estimate } \\
(\text { t-stat })\end{array}$ & N & R-Squared & F-value \\
\hline Regression B & Treasury & -4.18 & 0.00 & 31 & 0.02 & 0.502 \\
& & $\left(-18.99^{*}\right)$ & $(1.34)$ & & & 0.01 \\
Regression C & Treasury/GDP & -4.19 & 0.01 & 31 & 0.604 \\
& & $\left(-13.68^{*}\right)$ & $(0.73)$ & & & \\
\hline
\end{tabular}

*significant at $1 \%$ level.

For Regression B, the coefficient of Treasury holdings is insignificant and therefore it appears that the absolute amount of Treasury securities has no meaningful influence on the magnitude of the $d a y_{1}$ return. This is also the case for Regression Model C. The results provide no evidence that the amount of U.S. Treasury holdings scaled by GDP, explains none of the variation in returns. We look at the implications of these findings and conclude in the next section.

\section{Conclusions and Implications}

In this study we investigated the impact of the recent downgrade of U.S. Treasury debt on the leading stock market indices in 31 countries that own U.S. Treasury debt. We find that the stock indices of all these countries had sizable negative returns on the first trading day subsequent to the downgrade. While the negativity was not continuously apparent in trading days +2 to +5 , some markets recouped some of the losses more quickly and had significant positive returns. We examine the hypothesis that the amount of U.S. Treasury holdings a nation has impacts the magnitude of returns on its leading stock index. We find no evidence to support such a hypothesis, even when dividing Treasury holdings by the country's GDP. Thus we conclude that while the stock markets reacted negatively to the S\&P downgrade of long term Treasuries, the negative returns did not continue to drift downward. There is also no apparent penalty to equity markets associated with countries with large Treasury holdings measured on either an absolute or relative basis.

Kotlikoff (2006) asked the question a few years ago as to whether the United States was already bankrupt. Thakor (2006) who discussed the work of Kotlikoff (2006) disagrees, but cautions against excessive borrowing by the U.S. Treasury. Zivney and Marcus (1989) examined the impact of a temporary, technical default by the U.S. government and showed that yields increased following the default. Nippani, Liu and Schulman (2001) showed that under some circumstances, risk premiums were charged on short-term U.S. Treasury obligations, and Nippani and Smith (2010) showed the same for long-term U.S. Treasury debt. In another study, Liu, Shao and Yeager (2009) examine whether the financial markets charged a default risk premium on U.S. Treasury securities when the Federal government repeatedly reached their debt limits between 2002 and 2006. They find that a small risk premium was charged the first two times and no premium was charged in the last two recurrences. All this de facto evidence shows that the U.S. Treasury's securities were assessed a default risk premium during the time they were considered default-risk 
free by rating agencies. Now, one agency gave de jure status to this scenario, which according to its own report was pessimistic about the capacity of Congress and the administration to be able to leverage their agreement into a broader fiscal consolidation plan.

Our study has significant implications for participants in the stock and bond markets. It is also of interest to academics and practitioners alike. First, we showed that the stock markets around the world reacted very negatively to the ratings downgrade of long-term U.S. Treasury securities. We also demonstrated that the return magnitude is not impacted by the amount of a country's Treasury holdings. The fact that the amount of U.S. Treasury debt held was not useful in explaining the return variation is not surprising considering that U.S. Treasury prices actually rose following the announcement. It appears that while equity investors reacted adversely to the downgrade, there is no evidence this downgrade will ultimately lead to default. For academics, this study is of interest in that it shows how the market reacts to the increased riskiness of a rate considered by several generations to be risk-free. Market makers may increasingly look for an alternate rate or perhaps a combination of rates to proxy for the risk-free rate of return. Future studies perhaps will focus on other impacts of this downgrade, especially on international bond markets.

\section{Acknowledgements}

We thank John Nguyen, Ceyda Altun and Martins Oguntunde for graduate assistance.

\section{References}

Brooks, R., Faff, W. R., Hillier, D., \& Hillier, J. (2004). The national market impact of sovereign rating changes. Journal of Banking and Finance, 28(1), 233. http://dx.doi.org/10.1016/S0378-4266(02)00406-5

Elliott, L., Treanor, J., \& Rushe, D. (2011, August 5). The Guardian. Retrieved October 25, 2011 from http://www.guardian.co.uk/business/2011/aug/05/ftse-slumps-us-jobs-data.

Ferreira, A. M., \& Gama, M. P. (2007). Does sovereign debt ratings news spill over to international stock markets? Journal of Banking and Finance, 31(10), 3162. http://dx.doi.org/10.1016/j.jbankfin.2006.12.006

Hooper, V., Hume, T., Kim, S. J. (2008). Sovereign rating changes - Do they provide new information for stock markets? Economic Systems, 33(2), 142. http://dx.doi.org/10.1016/j.ecosys.2007.05.002

Kotlikoff, L. J. (2006). Is the United States Bankrupt? Review, 88(4), 235-249. Federal Reserve Bank of St. Louis.

Liu, P., Shao, Y., \& Yeager, T. J. (2009). Did the repeated debt ceiling controversies embed default risk in U.S. Treasury Securities? Journal of Banking and Finance, 33, 1464-1471. http://dx.doi.org/10.1016/j.jbankfin.2009.02.012

Meinero, M. M. (2011, August 8). CNN. Retrieved October 25, 2011, from CNN money http://money.cnn.com/2011/08/07/markets/world_markets_downgrade/index.htm.

Newey, W., \& West, K. (1987). A Simple Positive Semi-Definite Hetroskedasticity and autocorrelation consistent ovariance matrix. Econometrica, 55(1987), 707-708. http://dx.doi.org/10.2307/1913610

Nippani, S., \& Smith, S. D. (2010). The increasing default risk of U.S. Treasury securities due to the financial crisis. Journal of Banking and Finance, 34, 2472-2480. http://dx.doi.org/10.1016/j.jbankfin.2010.04.005

Nippani, S., Liu, P., \& Schulman, C. T. (2001). Are treasury securities free of default? Journal of Financial and Quantitative Analysis, 36(2), 251-266. http://dx.doi.org/10.2307/2676273

Pukthuanthong-Le, P. K., Elayan, A. F., \& Rose, C. L. (2007). Equity and debt market responses to sovereign credit rating announcment. Global Finance Journal, 18(1), 47. http://dx.doi.org/10.1016/j.gfj.2006.10.001

Swann, Nikola G. (2011). Research Update: United States of America Long-Term Rating Lowered To 'AA+' On Political Risks And Rising Debt Burden; Outlook Negative. Standard \& Poor's Global Credit Portal Ratings Direct. August 5.

Thakor, A. (2006). Is the United States bankrupt? Commentary. Review, 88(4), 251-257. Federal Reserve Bank of St. Louis.

Van Landschoot, A. (2008). Determinants of yield spread dynamics: Euro versus U.S. dollar corporate bond. Journal of Banking and Finance, 32, 2597-2605. http://dx.doi.org/10.1016/j.jbankfin.2008.05.011

Zivney, T. L., \& Marcus, R. D. (1989). The day the United States defaulted On Treasury bills. The Financial Review 24(3), 475-479. http://dx.doi.org/10.1111/j.1540-6288.1989.tb00353.x 


\section{Notes}

Note 1. See Swann, Nikola G. Research Update: United States of America Long-Term Rating Lowered To 'AA+' On Political Risks And Rising Debt Burden; Outlook Negative. Standard \& Poor's Global Credit Portal Ratings Direct. August 5 , 2011. Available at http://www.standardandpoors.com/servlet/BlobServer?blobheadername3=MDT-Type\&blobcol=urldata\&blobtable= MungoBlobs\&blobheadervalue $2=$ inline $\% 3 B+$ filename\%3DUS_Downgraded_AA\%2B.pdf\&blobheadername $2=$ Con tent-Disposition\&blobheadervalue $1=$ application $\% 2$ Fpdf\&blobkey=id\&blobheadername $1=$ content-type\&blobwhere $=1243942957443 \&$ blobheadervalue $3=$ UTF- 8

Note 2. Elliott, Larry, Treanor, Jill and Rushe, Dominic "U.S. Credit rating downgraded to AA+ by Standard and Poor's" posted on guardian.co.uk on Friday, 5 August 2011 at 15.11 EDT. The actual website is: http://www.guardian.co.uk/business/2011/aug/05/ftse-slumps-us-jobs-data.

Note 3. SeeMeinero, Mark M. "Europe, Asia Stocks Close sharply lower". At: http://money.cnn.com/2011/08/07/markets/world_markets_downgrade/index.htm.

Note 4. http://www.treasury.gov/resource-center/data-chart-center/tic/Documents/mfh.txt.

Note 5. See Nippani, S., Liu, P. and Schulman, C.T., “Are Treasury Securities Free of Default?” Journal of Financial and Quantitative Analysis, 36(2), 251-266. 